\title{
Effluent Quality Monitoring in Petrol Stations: Northern Thailand
}

\author{
Arunpak Pitakpong* \\ Department of Environmental Health, School of Medicine, University of Phayao, \\ Thailand
}

\begin{abstract}
Article Type: Article
Article Citation: Arunpak Pitakpong. Effluent quality monitoring in petrol stations: Northern Thailand. Indian Journal of Science and Technology. 2020; 13(01), 40-50.D0l: 10.17485/ijst/2020/ v013i01/148626
\end{abstract}

Received date: November 3, 2019

Accepted date: December 7, 2019

*Author for correspondence:

Arunpak Pitakpong

aompitakpong@gmail.com 9

Department of Environmental Health,

School of Medicine, University of

Phayao, Thailand

\begin{abstract}
Objectives: To study the effluent water quality and to compare the number of additional services within the petrol stations. Methods: Effluent water quality of 22 petrol stations around the Ping River in Thailand was assessed. The effluent samples were collected by grab sampling method, analyzed the water quality index ( $\mathrm{pH}, \mathrm{COD}, \mathrm{SS}$, and $\mathrm{O} \& \mathrm{G})$ in a laboratory, and compared the data of result analysis by mean and a percentage between the petrol stations with additional services and the petrol stations without additional services. Findings: The results of the research found that the petrol stations were only passed the standard criteria according to effluent quality of 45.45 percent. The data were separately analyzed according to the effluent quality index, the $\mathrm{pH}$ values passed the highest criteria of 90.91 percent, and the COD values passed the least criteria of 54.55 percent. Comparison of data between the additional services and the effluent quality within the petrol stations found that most of the petrol stations without additional services passed the standard criteria more than the petrol stations with additional services. Application/ improvements: Good effluent management should focus on additional services within stations, the future should study the knowledge and understanding of entrepreneurship, area, and determine the quantity of accessing those additional services.
\end{abstract}

Keywords: Effluent Quality, Petrol Stations, Monitoring, Northern Thailand.

\section{Introduction}

Water is an important element in a human cell, body and life that must be used for consumption (drinking, washing, cleaning, cooking and growing our food) as well as many other things in daily life [1]. Human receives many benefits from water resources including the activities of human culture and traditions [2]. The fact that nowadays water sources are increasingly deteriorated by humans who overuse water without realization 
and consciousness to maintain water resources [3] even though the global water is only $2 \%$ freshwater fit for human use [4]. It was reported that only $20 \%$ of communities in developing countries can access clean water [5].

There are concerns regarding contamination with toxic at very low concentrations are not only cytotoxic but also carcinogenic and mutagenic in nature [6]; chemical pesticides are toxic substances that are specifically designed to destroy biological organisms [7]; accumulation of heavy metals (cadmium, copper, lead, nickel, zinc, etc.) [8] cannot be broken down to non-toxic forms and have long-lasting effects on the ecosystem [6]. Oil or gas or waste spills are classified as sources of pollutants and contaminants [9] that oil and grease including fuels, motor oil, lubricating oil, hydraulic oil, cooking oil, and animal-derived fats and oils [10], pathogenic microorganisms (bacteria, fungi, viruses) are hazardous to the hydrogeological environment that enter this environment from waste disposal and treatment areas including cause of various diseases [9]. Such contaminants can still be a threat for a long time in the environment $[6,8-9]$ that are mixed into the aquatic environment can have deleterious health effects on human life, aquatic biota [8], animal, plant health and the environment [7].

Improper disposal of effluent and the problems of wastewater from human activities such as household or hospital waste, industrial waste and agricultural waste discharged into surface water source resulting in an increase of pollutants in river that are caused a high level of chemical oxygen demand (COD), suspended solids (SS) [11] and oil and grease $(O \& G)$ [10]. Such water is unsuitable for drinking, irrigation, aquatic life and risk to human health [11]. The content of household waste collects in the septic tank that is often discharged to the river or roads or lands and wastewater flows with a portion into the surrounding soil, leading to contamination [12].

The petrol stations are one of the activities that are controlled as the sources of wastewater. Now a day, Thai petrol stations are service more than the petrol service, formerly known as only the station of petrol service but the current petrol stations also consist of various additional services within the petrol stations. Petrol stations also include activities within petrol stations such as a 24-hours convenience store, restrooms, restaurants, cafes, car service stations, etc. Petrol stations where water is used for a lot of activities such as oil contamination from the use of water for cleaning up the area, wastewater from washing, wastewater from restrooms etc [13]. Wastewater by oil, gasoline, and other petroleum derivatives are that harmful effluents are discharged into the aquatic environment and disturb aquatic ecosystems. All petrol stations must have an effluent receptor system to separate suspended solids, oil and grease from wastewater before it conducts the wastewater treatment [14].

In this study, effluent samples of 22 petrol stations were analyzed $\mathrm{pH}$, chemical oxygen demand (COD), suspension solids (SS) and oil and grease (O\&G) and comparison of petrol stations with or without additional services and effluent quality of the petrol stations that use as an appropriate guideline information, planning and management including wastewater is passed through the wastewater treatment system of petrol station that has a quality standard. 


\section{Materials and methods}

\subsection{Sample group}

In this research, the researcher selected a sample of 22 petrol stations located within the responsibility area of the Local Administrative Organization of Ping River according to the determination by Regional Environmental Office 4 in Thailand.

\subsection{Effluent Quality Analysis}

The point selection where the effluent was discharged from the petrol stations or the effluent at the last point would be drained away from the petrol stations. In the data collection process, effluent samples were collected by grab sampling method. Samples were added in $2 \mathrm{~L}$ high-density polyethylene (HDPE) bottles and amber reagent bottle (wide mouth) and stored at $4^{\circ} \mathrm{C}$. Effluent samples were analyzed water quality index in the laboratory. Measurements were as follows: $\mathrm{pH}$, chemical oxygen demand (COD), suspension solids (SS) and oil and grease (O\&G) in accordance with [15].

\subsection{Characteristics of Additional Services in the Petrol Stations}

The type of additional services in 22 petrol stations was collected using an owner survey method. Such data were divided into the petrol stations with additional services and the petrol stations without additional services and then a comparison of petrol stations with or without additional services and effluent quality data by mean and percentage from the laboratory.

\section{Results and Discussion}

\subsection{Effluent Quality from Petrol Stations}

In this research, the researcher has studied the effluent quality from the petrol stations located within the responsibility area of the Local Administrative Organization of Ping River according to determination by Regional Environmental Office 4 in Thailand of 22 stations. All of the data were collected from effluent through the wastewater treatment system and effluent was drained out to the outside station of 31 points by comparison with the effluent draining control standard from petrol stations that were $\mathrm{pH}$, chemical oxygen demand (COD), suspended solids (SS) and oil and grease (O\&G), as showed in Table 1.

Table 1 found that most of the petrol stations were not passed the criteria of effluent quality standards. 10 petrol stations were only passed the criteria of the effluent quality standard by percentage representation of 45.45 percent. Analysis of each effluent quality index found that 20 petrol stations were passed the criteria of $\mathrm{pH}$ value according to effluent quality standards by percentage representation of 90.91 percent. Station 7 and station 3 had the highest $\mathrm{pH}$ values in all of the petrol stations that had $\mathrm{pH}$ values of 10.6 
TABLE 1. Effluent quality from petrol stations

\begin{tabular}{|c|c|c|c|c|c|}
\hline \multirow{2}{*}{ Petrol stations } & \multicolumn{4}{|c|}{ Effluent quality index } & \multirow{2}{*}{$\begin{array}{l}\text { Effluent quality } \\
\text { standard }\end{array}$} \\
\hline & pH & COD (mg/L) & SS (mg/L) & O\&G (mg/L) & \\
\hline Station 1 & 7.3 & 35.2 & 23 & 3.57 & Pass \\
\hline Station 2 & 7.6 & 244 & 10 & 3.16 & Fail \\
\hline Station 3 & 9.8 & 244 & 27 & 7.37 & Fail \\
\hline Station 4 & 7.7 & 105.6 & 24 & 5.13 & Pass \\
\hline Station 5 & 6.2 & 656 & 98 & 49.4 & Fail \\
\hline Station 6 & 7.6 & 265.6 & 60 & N/A & Fail \\
\hline Station 7 & 10.6 & 113.81 & 8 & 3.27 & Fail \\
\hline Station 8 & 7.6 & 370.07 & 9 & 3.42 & Fail \\
\hline Station 9 & 7.3 & 455.5 & 12 & 5.5 & Fail \\
\hline Station 10 & 7 & 2704.38 & 43 & 28.35 & Fail \\
\hline Station 11 & 7.9 & 597.81 & 26 & 5 & Fail \\
\hline Station 12 & 8 & 199.27 & 13 & 3.13 & Pass \\
\hline Station 13 & 7.6 & 72.86 & 32 & 10 & Pass \\
\hline Station 14 & 7.7 & 133.86 & 37 & 15.5 & Fail \\
\hline Station 15 & 6 & 970.04 & 76 & 29.1 & Fail \\
\hline Station 16 & 7.2 & 15.25 & 5 & 1.79 & Pass \\
\hline Station 17 & 8 & 35.58 & 3 & 1.55 & Pass \\
\hline Station 18 & 7.9 & 25.42 & 9 & 4.73 & Pass \\
\hline Station 19 & 7.7 & 893.8 & 75 & 69.68 & Fail \\
\hline Station 20 & 8.4 & 157.58 & 3 & 9.04 & Pass \\
\hline Station 21 & 7.1 & 26.44 & 6 & 4.96 & Pass \\
\hline Station 22 & 8.3 & 5.08 & 1 & 4.51 & Pass \\
\hline $\begin{array}{l}\text { Effluent quality } \\
\text { standard }\end{array}$ & $5.5-9.0$ & 200 & 60 & 15 & \\
\hline
\end{tabular}

and 9.8, respectively. Station 15 had the least $\mathrm{pH}$ values in all of the petrol stations that had $\mathrm{pH}$ values of 6 .

19 petrol stations were passed the criteria of suspended solids (SS) according to effluent quality standards by percentage representation of 86.36 percent. Station 5 and Station 15 had the highest suspended solids in all of the petrol stations that had a value of $98 \mathrm{mg} / \mathrm{L}$ and $76 \mathrm{mg} / \mathrm{L}$, respectively. Station 22 had the least suspended solids in all of the petrol stations that had a value of $1 \mathrm{mg} / \mathrm{L}$.

17 petrol stations were passed the criteria of oil and grease $(O \& G)$ according to effluent quality standards by percentage representation of 77.27 percent. Station 19 and Station 5 had the highest oil and grease in all of the petrol stations that had a value of $69.68 \mathrm{mg} / \mathrm{L}$ and $49.4 \mathrm{mg} / \mathrm{L}$, respectively. Station 17 had the least oil and grease in all of the petrol stations that had a value of $1.55 \mathrm{mg} / \mathrm{L}$. However, Station 16 was unable to measure oil and grease because the analytical tools were in the maintenance process that was deemed to pass the criteria of standards.

12 petrol stations were passed the criteria of chemical oxygen demand (COD) according to effluent quality standards by percentage representation of 54.55 percent. Station 10 and Station 15 had the highest chemical oxygen demand in all of the petrol stations that had a value of 2,704.38 mg/L and $970.04 \mathrm{mg} / \mathrm{L}$, respectively. Station 22 had the least chemical oxygen demand in all of the petrol stations that had a value of $5.08 \mathrm{mg} / \mathrm{L}$. 


\subsection{Characteristics of Additional Services in the Petrol Stations}

In this research, the researcher has studied the characteristics of the additional services within 22 petrol stations, as showed in Table 2 .

From Table 2, the results found that the restroom was the most numerous additional services within all petrol stations (22 stations) by percentage representation of 54.55 percent. The petrol stations mainly had fuel distribution services and also a restroom must be serviced into every station, followed by convenience stores (10 stations) and cafes (10 stations) by percentage representation of 45.45 percent, and the worker dormitory was the least numerous additional services within all petrol stations (1 station)by percentage representation of 4.55 percent.

\subsection{Comparison of Data Between Additional Services and Effluent Quality Within the Petrol Stations}

In this research, the petrol stations were divided into 2 groups: (1) petrol stations without additional services of 8 stations, and (2) petrol stations with additional services of 14

TABLE 2. Additional services within petrol stations

\begin{tabular}{|c|c|c|c|c|c|c|}
\hline \multirow{2}{*}{$\begin{array}{l}\text { Petrol } \\
\text { stations }\end{array}$} & \multicolumn{6}{|c|}{ Additional services within petrol stations } \\
\hline & $\begin{array}{c}\text { Convenience } \\
\text { store }\end{array}$ & Cafe & Restaurant & Restroom & $\begin{array}{l}\text { Service } \\
\text { station }\end{array}$ & $\begin{array}{c}\text { Worker } \\
\text { dormitory }\end{array}$ \\
\hline 1 & & & & $\checkmark$ & & \\
\hline 2 & $\checkmark$ & $\checkmark$ & & $\checkmark$ & & \\
\hline 3 & $\checkmark$ & & & $\checkmark$ & $\checkmark$ & $\checkmark$ \\
\hline 4 & $\checkmark$ & & & $\checkmark$ & & \\
\hline 5 & $\checkmark$ & $\checkmark$ & $\checkmark$ & $\checkmark$ & & \\
\hline 6 & $\checkmark$ & $\checkmark$ & $\checkmark$ & $\checkmark$ & & \\
\hline 7 & $\checkmark$ & $\checkmark$ & $\checkmark$ & $\checkmark$ & $\checkmark$ & \\
\hline 8 & & & & $\checkmark$ & & \\
\hline 9 & $\checkmark$ & $\checkmark$ & & $\checkmark$ & & \\
\hline 10 & $\checkmark$ & & & $\checkmark$ & & \\
\hline 11 & & $\checkmark$ & & $\checkmark$ & & \\
\hline 12 & & & & $\checkmark$ & & \\
\hline 13 & & $\checkmark$ & & $\checkmark$ & & \\
\hline 14 & $\checkmark$ & $\checkmark$ & & $\checkmark$ & & \\
\hline 15 & $\checkmark$ & & & $\checkmark$ & & \\
\hline 16 & & $\checkmark$ & & $\checkmark$ & & \\
\hline 17 & & & & $\checkmark$ & & \\
\hline 18 & & & & $\checkmark$ & & \\
\hline 19 & & $\checkmark$ & & $\checkmark$ & $\checkmark$ & \\
\hline 20 & & & & $\checkmark$ & & \\
\hline 21 & & & & $\checkmark$ & & \\
\hline 22 & & & & $\checkmark$ & & \\
\hline Total & 10 & 10 & 5 & 22 & 3 & 1 \\
\hline Percentage & 45.45 & 45.45 & 22.73 & 100.00 & 13.64 & 4.55 \\
\hline
\end{tabular}


stations. And then, compared with the effluent quality data of the petrol stations, the result as shown in Figure 1.

From Figure 1, the results showed that the petrol stations without additional services passed higher the standard criteria than the petrol stations with additional services. The data were separately analyzed according to effluent quality index, the results were as follows:

\subsection{1. $\mathrm{pH}$}

The results of $\mathrm{pH}$ analysis found that the petrol stations without additional services (left) showed the $\mathrm{pH}$ value in the standard criteria of 8 stations by percentage representation of 100.00 percent, and the petrol stations with additional services (Right) showed the $\mathrm{pH}$ value in standard criteria of 12 stations by percentage representation of 5.71 percent as shown in Figure 2.

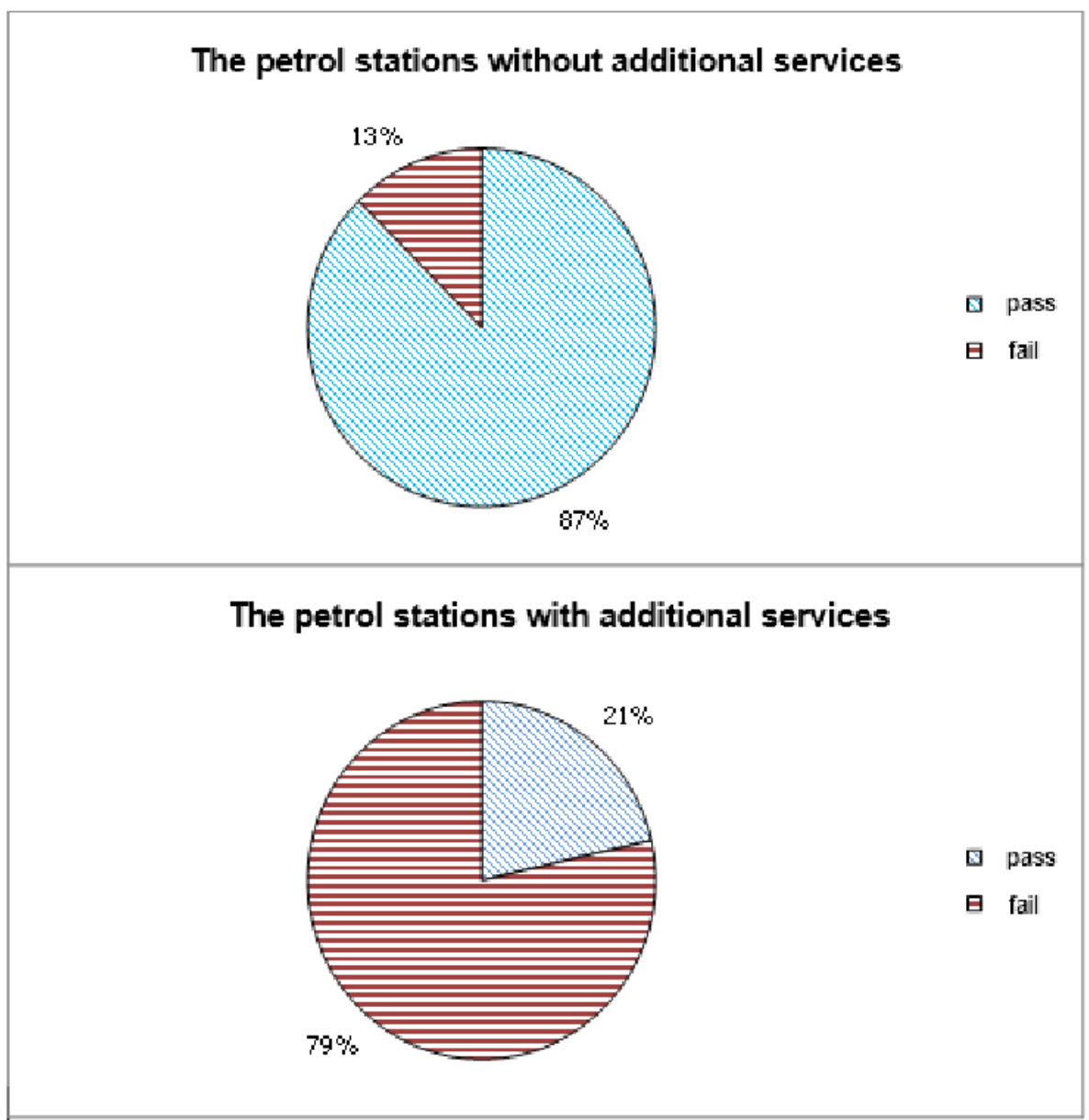

FIGURE 1. The number of additional services compared to the effluent quality. 


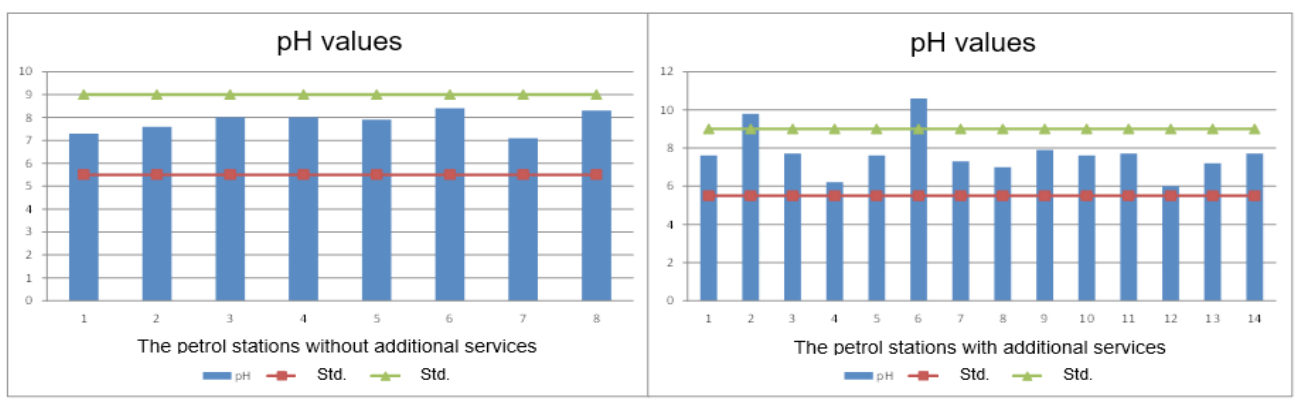

Std. $=$ Standard

FIGURE 2. $\mathrm{pH}$ value.

\subsubsection{Chemical Oxygen Demand (COD)}

The results of COD analysis found that the petrol stations without additional services (left) showed COD values in the standard criteria of 7 stations by percentage representation of 87.5 percent, and the petrol stations with additional services (Right) showed COD values in the standard criteria of 5 stations by percentage representation of 35.71 percent as shown in Figure 3.

\subsubsection{Suspended Solids (SS)}

The results of SS analysis found that the petrol stations without additional services (left) showed SS value in the standard criteria of 8 stations by percentage representation of 100.00 percent, and the petrol stations with additional services (Right) showed SS value in the standard criteria of 11 stations by percentage representation of 78.57 percent as shown in Figure 4.

\subsubsection{Oil and Grease (O\&G)}

The results of $O \& G$ analysis found that the petrol stations without additional services (left) showed O\&G values in the standard criteria of 8 stations by percentage representation of 100.00 percent, and the petrol stations with additional services (Right) showed SS values

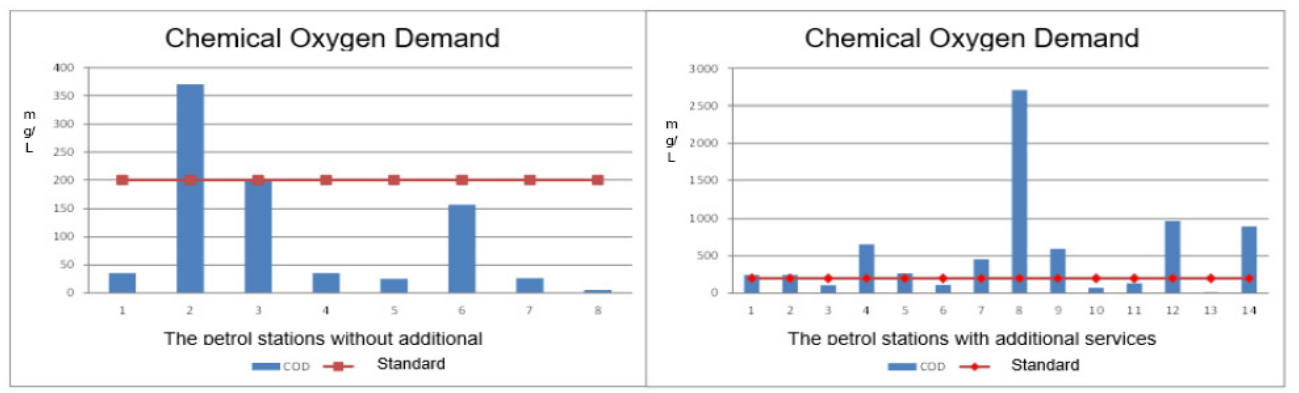

FIGURE 3. Chemical oxygen demand (COD). 

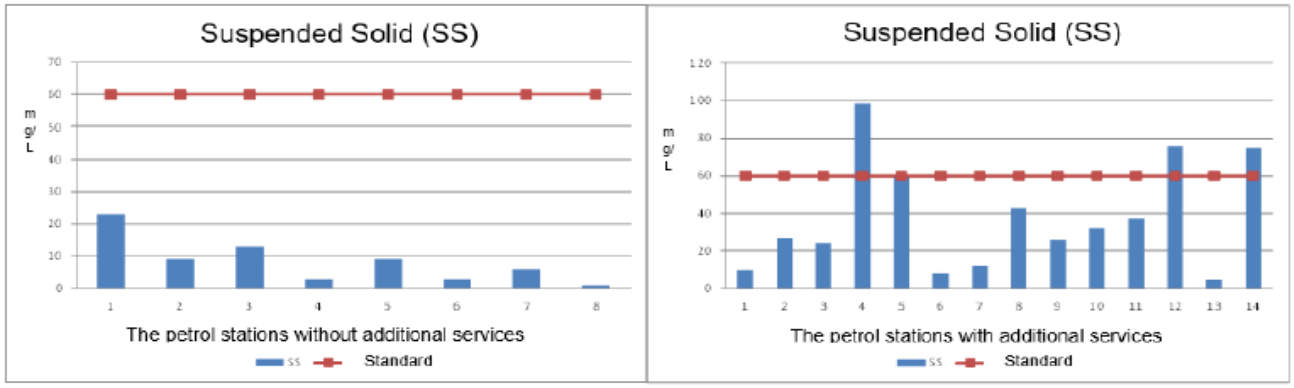

FIGURE 4. Suspended solids (SS).

in the standard criteria of 8 stations by percentage representation of 57.14 percent as shown in Figure 5.

From the study of the effluent quality within the petrol stations showed that the wastewater treatment system of the petrol stations could not still treat the wastewater according to the standard criteria. However, all of the samples had only 45.45 percent that passed the standard criteria according to the effluent quality index. Moreover, most of the COD values were not passed the standard criteria according to the effluent quality index. Most of the COD values within the petrol stations were concerned because of carwashing water from the car service stations that were the cause of the wastewater into the environment [16].

As for the effluent quality index, followed by oil and grease (O\&G). The petrol stations had oil and grease values exceeding the standard criteria which were mainly had additional services such as restaurants, cafes, and convenience stores. The food ingredients were always had some vegetable oil as a component that resulted in wastewater [17]. The coffee was composed of some milk and butter which contained oil and grease as a component [18], therefore, they were probably caused the oil and grease values in the petrol stations more than the standard criteria. Including, the car service stations affected the increase of oil and grease values because the water was used to wash a car that might contaminate with oil and grease [19]. These additional services were the cause of the contaminated water of oil and grease that exceeded the standard criteria and affected the environment.

Most of suspended solid (SS) values within the petrol stations passed the standard criteria. However, the SS values of some petrol stations had more excessive than the standard

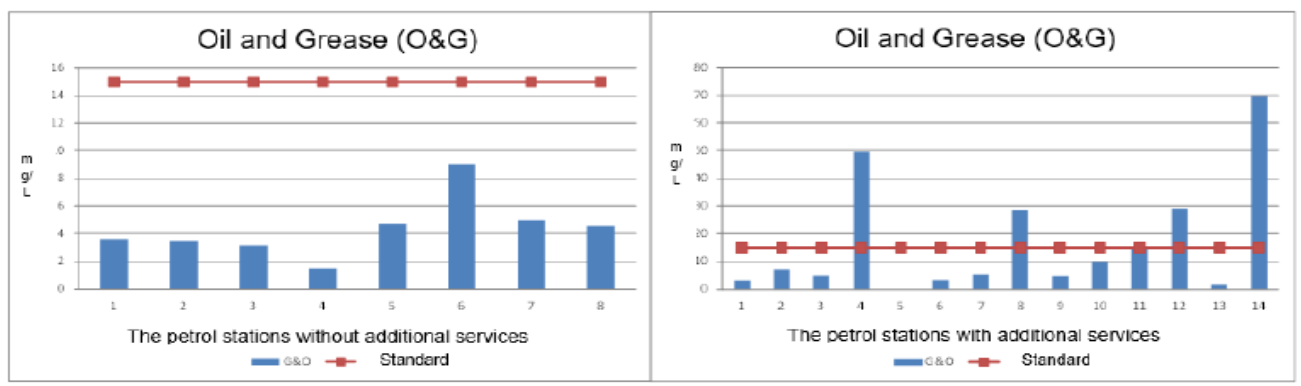

FIGURE 5. Oil and grease $(\mathrm{O} \& \mathrm{G})$. 
criteria due to the contamination of dirt into the drainage channels such as sediment (soil and/or sand), and various organic matter flowed though into the wastewater treatment system and discharged into the external water sources to be the cause of dirtiness in water sources affecting aquatic plants and/or algae could not be photosynthesized [20].

The $\mathrm{pH}$ values within the petrol stations were passed the most standard criteria according to the effluent quality index. However, the $\mathrm{pH}$ values of some petrol stations were higher than the standard criteria due to the contamination of effluent from restaurants that entered the wastewater treatment system of the petrol stations, the wastewater that affected the $\mathrm{pH}$ values increasingly such as lemon juice, vinegar, and washing water. They had cleaned or washed the utensils before they poured the washing water into the drainage channels without the treatment that affected the wastewater treatment system of the petrol stations regarding the heavily burdensome treatment. Hence, these were the cause of $\mathrm{pH}$ values exceeding the standard criteria [21].

On the comparison between the number of additional services and the effluent quality within the petrol stations were found that the petrol stations without additional services were mainly passed the standard criteria of effluent quality more than the petrol stations with additional services (restaurants, supermarkets, convenience stores, car services, etc. that were the source of wastewater) [22]. The petrol stations were separately analyzed according to effluent quality index; the results found that the petrol stations with additional services as convenience stores within the petrol stations had COD values exceeding the standard criteria.

\section{Conclusion}

The study of the effluent quality ( $\mathrm{pH}$, chemical oxygen demand (COD), suspension solids (SS) and oil and grease (O\&G) ) and comparison between the number of additional services and the effluent quality within the petrol stations of 22 stations in Northern of Thailand concluded that the petrol stations were only passed the standard criteria according to effluent quality index of 45.45 percent (10 stations). The data were separately analyzed according to effluent quality index, the $\mathrm{pH}$ values within the petrol stations passed the most the standard criteria according to effluent quality index of 90.91 percent (20 stations), and most of the COD values passed the least the standard criteria according to effluent quality index of 54.55 percent (12 stations). The petrol stations without additional services were mainly passed the standard criteria of effluent quality more than the petrol stations with additional services. Hence, the good management of effluent quality should be to focus on additional services within the fuel station that the future should study the knowledge and understanding of entrepreneurship, area size, and determine the quantity of accessing those additional services.

\section{Acknowledgment}

The author would like to offer particularly thanks to the School of Medicine, University of Phayao, Thailand. 


\section{References}

1. Hossain MZ. Water: the most precious resource of our life. Global Journal of Advanced Research. 2015; 2(9), 1436-1445.

2. Water \& culture the international decade for water 2005-2015. https://www.who.int/water sanitation_health/Water\&cultureEnglishv2.pdf. Date accessed: 22/03/2003.

3. Tundisi JG. Water resources in the future: problems and solutions. Estudos Avancados. 2008; 22(63), 7-16.

4. Mugagga F, Nabaasa BB. The centrality of water resources to the realization of Sustainable Development Goals (SDG). A review of potentials and constraints on the African continent. International Soil and Water Conservation Research. 2016; 4, 215-223.

5. Fatimah I, Sahroni I, Putra HP, Nugraha MR, Hasanah UA. Ceramic membrane based on TiO2modified kaolinite as a low cost material for water filtration. Applied Clay Science. 2015; 118, 207-211.

6. Dixit R, Wasiullah, Malaviya D, Pandiyan K, Singh UB, Sahu A, Shukla R, Singh BP, Rai JP, Sharma PK, Lade H, Paul D. Bioremediation of heavy metals from soil and aquatic environment: an overview of principles and criteria of fundamental processes. Sustainability. 2015; 7 , 2189-2212.

7. Rani K, Dhania G. Bioremediation and biodegradation of pesticide from contaminated soil and water - a noval approach. International Journal of Current Microbiology and Applied Sciences. 2014; 3(10), 23-33.

8. Ahmad S, Tabassum H, Alam A. Role of microbial bioremediation of heavy metal from contaminated soil: an update. International Journal of Biology, Pharmacy and Allied Sciences (IJBPAS). 2016; 5(7), 1605-1622.

9. Egboka BCE, Nwankwor GI, Orajaka IP, Ejiofor AO. Principles and problems of environmental pollution of groundwater resources with case examples from developing countries. Environmental Health Perspectives. 1989; 83, 39-68.

10. Fulazzaky MA, Omar R. Removal of oil and grease contamination from stream water using the granular activated carbon block filter. Clean Technologies and Environmental Policy. 2012; 14, 965-971.

11. Odigie JO. Harmful effects of wastewater disposal into water bodies: a case review of the Ikpoba river, Benin city, Nigeria. Tropical Freshwater Biology. 2014; 23, 87-101.

12. Ghawi AH. Study on the development of household wastewater treatment unit. Journal of Ecological Engineering. 2018; 19(2), 63-71.

13. Waste minimization and recovery toward sustainable petrol station. Waste minimization and recovery toward sustainable petrol station. https://www.researchgate. net/publication/283986281 Waste Minimization and Recovery toward Sustainable Petrol Station. Date accessed: 03/2019.

14. Oliveira-Martins CR, Grisolia CK. Toxicity and genotoxicity of wastewater from gasoline stations. Genetics and Molecular Biology. 2009; 32(4), 853-856.

15. Hayder G, Puniyarasen P. Identification and evaluation of wastes from biodiesel production process. Journal of Advanced Research in Applied Sciences and Engineering Technology. 2016; $3(1), 21-29$.

16. Mazumder D, and Mukherjee S. Treatment of automobile service station wastewater by coagulation and activated sludge process. International Journal of Environmental Science and Development. 2011; 2(1), 64-69.

17. Dkhissi O, Hakmaoui A El, Souabi S, Chatoui M, Jada A, Akssira M. Treatment of vegetable oil refinery wastewater by coagulation-flocculation process using the cactus as a bio-flocculant. Journal of Materials and Environmental Sciences. 2018; 9(1), 18-25. 
18. Kavitha RV, Kumar S, Suresh R, Krishnamurthy V. Performance evaluation and biological treatment of dairy waste water treatment plant by upflow anaerobic sludge blanket reactor. International Journal of Chemical \& Petrochemical Technology. 2013; 3(1), 9-20.

19. Asha MN, Chandan KS, Harish HP, Nikhileswar Reddy S, Sharath KS, Mini Liza G. Recycling of waste water collected from automobile service station. Procedia Environment Sciences. 2016; 35, 289-297.

20. Bornette G, Puijalon S. Response of aquatic plants to abiotic factors: a review. Aquatic Sciences. 2011; 73, 1-14.

21. Naserisafavi N, Chu MY. Evaluation of kitchen wastewater with additives. International Proceedings of Chemical, Biological and Environmental Engineering. 2017; 102, 57-64.

22. University curriculum development for decentralized wastewater management. http://www. ndwrcdp.org/documents/WU-HT-01-06/WUHT0106.pdf. Date accessed: 03/2005. 